\title{
Morteros de reparación basados en cal. Ensayos de envejecimiento acelerado
}

\author{
Repair mortars based on lime. Accelerated aging tests
}

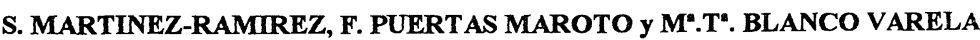 \\ IETCC/CSIC/ESPAÑA
}

Fecha de recepción:11-V-95

\section{RESUMEN}

Se ha estudiado el comportamiento frente a distintos ensayos de envejecimiento acelerado (ciclos de hielo/deshielo y cristalización de sales) de un nuevo mortero de cal con propiedades biocidas, destinado a la reparación monumental.

Se ha comprobado que los nuevos morteros (que llevan incorporado el biocida impregnado en una arcilla denominada sepiolita) tienen un comportamiento muy similar a los morteros de cal utilizados como referencia. Tras los ensayos de envejecimiento se ha visto que las propiedades biocidas de los morteros se mantienen.

\section{SUMMARY}

The behaviour under different accelerated aging tests (freeze/thaw and crystallization cycles) of a new lime mortar with biocide properties destinated to monumental repair has been studied.

New mortars (which have the biocide impregnated in a clay called sepiolite) have a similar behaviour to lime mortars used as a reference. After the aging tests, the biocide properties of the mortars have been tried.

\section{INTRODUCCIÓN}

Se considera prioritario en todo trabajo de reparación de obras del Patrimonio Historico-Artístico, el utilizar materiales lo más parecidos posibles (ya sea en sus características físicas, químicas, mecánicas) a los materiales originales del monumento. Asímismo, también es un requisito a tener en cuenta, que dichos materiales de reparación sean reversibles y que minimicen las causas de deterioro producidas en los mismos (1).

Desde la antigüedad, hasta aproximadamente el año 1300 , la cal fue el ligante mayoritariamente utilizado, tanto en la preparación de morteros como de hormigones (2). Una adecuada reparación de los morteros de esos

\section{INTRODUCTION}

The priority in Cultural Heritage research is the use of similar materials to the original ones in the monument (in physical, chemical, mechanical characteristics). In the same way, a condition worth taking into account is that the repair materials have to be reversible and have to minimize the decay causes produced on them (l).

From ancient times to approximately the year 1300 lime was the main binder used in mortars and concretes preparation (2). A suitable repair of mortars from those monuments would required the use of lime 
monumentos, requeriría el empleo de la cal como material ligante de dichos morteros.

Las causas de deterioro de los morteros, ya sean antiguos o de reparación, son fundamentalmente debidas a factores físicos tales como variaciones de temperatura, acción del viento, etc. A factores químicos, en los que se incluirán todos aquellos que lleven asociados algún tipo de reacción química $y$, finalmente, a factores biológicos relacionados con el crecimiento y desarrollo de diferentes tipos de microorganismos.

Ante estos hechos surgió la necesidad de diseñar morteros de reparación basados en cal, cuya propiedad fundamental sea el presentar propiedades biocidas.

Se ha diseñado (3), (4) un mortero de reparación basado en cal al que se adiciona sepiolita como soporte de un biocida y sobre el que se ha comprobado mantiene propiedades biocidas. Se seleccionó el pentaclorofenol $\left(\mathrm{Cl}_{5} \mathrm{C}_{6} \mathrm{OH}\right)$ como el biocida óptimo para adicionar al mortero.

La sepiolita es un silicato magnésico hidratado $\left(\mathrm{Si}_{12} \mathrm{Mg}_{8} \mathrm{O}_{30}(\mathrm{OH})_{4}\left(\mathrm{H}_{2} \mathrm{O}\right)_{4} 12 \mathrm{H}_{2} \mathrm{O}\right)$ que presenta una elevada capacidad de adsorción/absorción. Dicha propiedad se aprovecha para utilizar la sepiolita como material soporte del biocida.

En este artículo se presentan los resultados obtenidos al estudiar el comportamiento resistente de esos morteros de reparación frente a una serie de ensayos de envejecimiento acelerado, tales como hielo-deshielo y cristalización de sales. En dichos ensayos se estudiará el papel que juega la sepiolita en el deterioro de los materiales, así como el que los morteros mantengan las propiedades biocidas después de los ensayos de envejecimiento a que se han sometido.

\section{EXPERIMENTAL}

Se preparó un mortero de cal con relaciones árido/ligante $=3 / 1$ y H$_{2} \mathrm{O} /(\mathrm{cal}+$ sepiolita $)=0,9$, al que se adicionó sepiolita en diferentes concentraciones, así como sepiolita con el biocida retenido. El biocida seleccionado fue pentaclorofenol $\left(\mathrm{Cl}_{5} \mathrm{C}_{6} \mathrm{OH}\right)$. En la Tabla I se presentan las composiciones de los morteros preparados.

La cal apagada tiene un $97,5 \%$ de $\mathrm{Ca}(\mathrm{OH})_{2}$ y el árido es un árido silíceo del 98,9\% de pureza en $\mathrm{SiO}_{2}$. La sepiolita tiene un $78 \%$ de pureza y las principales impurezas son cuarzo, calcita y feldespatos.

Con dicho mortero se prepararon probetas cúbicas de 3,5 $\mathrm{cm}$ de lado que se sometieron a los ensayos de envejecimiento acelerado. as a binder material.

The causes of ancient or repair mortars decay, are mainly due to physical factors such as temperature changes, wind action, etc. or due to chemical factors in which a chemical reaction would be included and finally, due to biological causes related to the growth and development of different microorganisms.

The need of designing repair mortars based on lime which main characteristic be biocide properties, arises from the former facts.

A repair mortar based on lime with sepiolite added as a biocide support has been designed and its biocide properties have been tried. The optimum biocide to add to the mortar was selected and it resulted to be pentachlorophenol $\left(\mathrm{Cl}_{5} \mathrm{C}_{6} \mathrm{OH}\right)(3,4)$.

Sepiolite is a magnesium silicate hydrate $\left(\mathrm{Si}{ }_{12} \mathrm{Mg}_{8} \mathrm{O}_{30}(\mathrm{OH})_{4}\left(\mathrm{H}_{2} \mathrm{O}\right)_{4} 12 \mathrm{H}_{2} \mathrm{O}\right)$ that has a high adsorption/absorption capacity. This property of the sepiolite is used to support the biocide on it.

The results obtained in the study of strength behaviour of these repair mortars under different accelerated aging tests such as freeze/thaw and crystallization cycles are presented. In these tests, the sepiolite role in materials degradation will be studied, likewise the fact that mortars maintained their biocide properties after they have been submitted to the aging tests.

\section{EXPERIMENTAL}

A lime mortar with aggregate/binder relation $3 / 1$ and $\mathrm{H}_{2} \mathrm{O}$ /(lime + sepiolite) 0.9 was prepared and sepiolite was added in different concentrations, likewise the sepiolite with the retained biocide. The selected biocide was pentaclorophenol $\left(\mathrm{Cl}_{5} \mathrm{C}_{6} \mathrm{OH}\right)$. In Table I mortars composition is shown.

The slaked lime has $97.5 \% \mathrm{Ca}(\mathrm{OH})_{2}$ and the aggregate is a siliceous one with $98.9 \%$ of $\mathrm{SiO}_{2}$ pureness. The sepiolite is $78 \%$ pure and its main impurities are quartz, calcite and felspars.

With this mortar, cubic specimens of $3.5 \mathrm{~cm}$ side were prepared and submitted to accelerated aging tests. 
Dichos ensayos fueron los siguientes:

1.- Ciclos hielo/deshielo

2.- Cristalización de sales

2.1.- $\mathrm{NaCl}$

2.2.- $\mathrm{Na}_{2} \mathrm{SO}_{4}$
These tests were the following:

1.- Freeze/thaw cycles

2.- Crystallization tests

2.1.- $\mathrm{NaCl}$

2.2.- $\mathrm{Na}_{2} \mathrm{SO}_{4}$

TABLA I (TABLE I)

Composiciones de los morteros de cal y sepiolita

(Composition of lime and sepiolite mortars)

\begin{tabular}{|c|c|c|}
\hline arena/cal (sand/lime) & $\begin{array}{c}\text { agua/(cal + sep) } \\
\text { water (lime + sep) }\end{array}$ & \% sepiolita (\% sepiolite) \\
\hline \hline $3 / 1$ & 0,9 & 0 \\
\hline $3 / 1$ & 0,9 & 1 \\
\hline $3 / 1$ & 0,9 & 5 \\
\hline $3 / 1$ & 0,9 & $5^{*}$ \\
\hline
\end{tabular}

* indica que la sepiolita lleva retenido el biocida (means that sepiolite has the retained biocide)

\section{1.- Ciclos hielo/deshielo}

Se determinó el comportamiento de los morteros cuando se sometieron a variaciones climáticas de temperatura, basándose en la Norma UNE 67-034-86 (5).

El ensayo consistió en someter a los morteros a ciclos de hielo-deshielo. Para ello se introdujeron inicialmente las muestras en un tanque con $\mathrm{H}_{2} \mathrm{O}$ a temperatura ambiente $\left(25^{\circ} \mathrm{C}\right)$, durante $4 \mathrm{~h}$, asegurando que el $\mathrm{H}_{2} \mathrm{O}$ cubriera completamente las muestras para que la adsorción de agua fuera total por parte de las mismas. Transcurrido este tiempo, las probetas se introdujeron en la cámara frigorífica $\left(-4^{\circ} \mathrm{C}\right)$ durante $20 \mathrm{~h}$. Estos ciclos se repitieron 25 veces, al cabo de los cuales se realizó sobre las probetas un examen visual que permitió establecer una primera aproximación de los daños producidos en las muestras. Posteriormente, sobre ellas, se determinó la resistencia a compresión según la norma UNE 80-101 (6), la porosidad accesible al $\mathrm{H}_{2} \mathrm{O}$ y la densidad aparente, según las recomendaciones de la RILEM (7).

\section{2.- Cristalización de sales}

Se utilizaron dos sales inorgánicas que pueden producir efectos diferentes sobre el material: a) disolución saturada de $\mathrm{NaCl}$ y b) disolución al $7 \%$ de $\mathrm{Na}_{2} \mathrm{SO}_{4} \cdot 10 \mathrm{H}_{2} \mathrm{O}$

\section{1.- Freeze/thaw cycles:}

The mortars behaviour when submitted to climatic temperature variations was determined, based on UNE Normative 67-034-86 (5).

The test consisted in submitting mortars to freeze/thaw cycles. The samples were immersed initially in a water tank at ambient temperature $\left(25^{\circ} \mathrm{C}\right)$, during 4 hours. making sure that water was completely covering the samples to promote a total water adsorption. After this time, specimens were immersed in a frost chamber $\left(-4^{\circ} \mathrm{C}\right)$ during $20 \mathrm{~h}$. These cycles were repeated 25 times after which a visual examination of the specimens were done to established a first approximation of the damage produced. Afterward, the compressive strength according to UNE Normative 80-101(6) was determined, and the porosity accessible to water and the apparent density were determined according to RILEM recommendations (7).

\section{2.- Crystallization tests}

Two inorganic salts that can produced different effects on the material were used : a) $\mathrm{NaCl}$ saturated solution and b) $7 \% \mathrm{Na}_{2} \mathrm{SO}_{4} \cdot 10 \mathrm{H}_{2} \mathrm{O}$ solution. 


\section{1.- Cristalización en $\mathrm{NaCl}$}

Este ensayo se realizó en base a las recomendaciones de la RILEM (7), aunque con algunas modificaciones para adaptarlos a este tipo de materiales, que a continuación indicaremos.

Las probetas se sometieron a ciclos de inmersión/secado. Inicialmente las probetas se sumergieron en la disolución saturada de $\mathrm{NaCl}\left(35,7 \mathrm{~g} \mathrm{NaCl} / 100 \mathrm{cc}_{2} \mathrm{O}\right)$ durante $48 \mathrm{~h}$, al final de las cuales las probetas se secaron a $105^{\circ} \mathrm{C}$ durante $24 \mathrm{~h}$. Estos ciclos se repitieron 15 veces.

Una vez finalizados los ciclos, las probetas se desalinizaron. Para ello, se sumergieron en agua desionizada durante $24 \mathrm{~h}$., retirando el agua y repitiéndose el proceso durante 7 días.

Sobre estas probetas se realizaron los siguientes ensayos:
a) Pérdidas de peso
b) Determinación de la resistencia a compresión (UNE 80-101 (6))
c) Porosidad accesible al $\mathrm{H}_{2} \mathrm{O}$ (Recomendaciones RILEM (7))

d) Densidad aparente (Recomendaciones RILEM

\section{2.- Cristalización en $\mathrm{Na}_{2} \mathrm{SO}_{4}$}

Este ensayo se basa en la Norma ASTM C88-83 (8), aunque con las modificaciones oportunas para la adecuación de la norma a este tipo de materiales.

Las probetas cúbicas $(3,5 \mathrm{~cm}$. de lado) se sumergieron inicialmente en una disolución al $7 \%$ en peso de $\mathrm{Na}_{2} \mathrm{SO}_{4} 10 \mathrm{H}_{2} \mathrm{O}\left(7,525 \mathrm{~g} \mathrm{Na}_{2} \mathrm{SO}_{4} 10 \mathrm{H}_{2} \mathrm{O} / 100 \mathrm{cc} \mathrm{H}_{2} \mathrm{O}\right)$. Los ciclos son iguales a los descritos en el ensayo de cristalización de sales en la disolución de $\mathrm{NaCl}$.

\section{RESULTADOS Y DISCUSIÓN}

\section{1.- Ciclos hielo/deshielo}

En la Foto 1, se presenta el aspecto inicial de las probetas antes de someterlas a los ciclos.

En la Foto 2 se muestra el aspecto de las probetas después de someterlas a los 25 ciclos de hielo/deshielo. $\mathrm{El}$ primer examen visual, indica que los morteros no han sufrido grandes modificaciones en su aspecto externo.

En la Tabla II se muestran los valores de la resistencia a compresión de las muestras sometidas a ciclos y junto a los de los morteros iniciales, sin someterlos a ningún

\section{1.- Crystallization in $\mathrm{NaCl}$ medium}

This test was done according to RILEM recommendations (7), although some variations were done to adapt it to this kind of materials and they are point out next.

The specimens underwent wet/dry cycles. Initially, samples were immersed in $\mathrm{NaCl}$ saturated solution (35.7 $\left.\mathrm{g} \mathrm{NaCl} / 100 \mathrm{cc} \mathrm{H}_{2} \mathrm{O}\right)$ during $48 \mathrm{~h}$., after which the specimens were dried at $105^{\circ} \mathrm{C}$ during $24 \mathrm{~h}$. These cycles were repeated 15 times.

Once the cycles were over, the specimens were desalted. To make this, they were submerged in deionized water during 24 hours, removing the water after and repeating the procedure during 7 days.

On these specimens, the following tests were done:

a) Weight loss

b) Compressive strength determination (UNE 80-101

(6))

c) Porosity accesible to water (RILEM

recommendations (7))

d) Apparent density (RILEM recommendations (7))

\section{2- Crystallization in $\mathrm{Na}_{2} \mathrm{SO}_{4}$ medium}

This test is based on ASTM normative C88-83 (8), although with the suitable variations to adequate it to this kind of materials.

The cubic specimens $(3.5 \mathrm{~cm}$ side) were initially immersed in a $7 \%$ in weight $\mathrm{Na}_{2} \mathrm{SO}_{4} \mathrm{IOH}_{2} \mathrm{O}$ solution (7.525 $\mathrm{g} \mathrm{Na}_{2} \mathrm{SO}_{4} 10 \mathrm{H}_{2} \mathrm{O} / 100 \mathrm{cc} \mathrm{H}_{2} \mathrm{O}$ ). The cycles are the same described in the case of $\mathrm{NaCl}$ solution crystallization test.

\section{RESULTS AND DISCUSSION}

\section{1.- Freeze/thaw cycles}

In Photo 1, the initial aspect of the specimens before submitted them to the cycles is shown.

In Photo 2, the aspect of the specimens after undergoing the 25 cycles freeze-thaw is shown. The first visual examination points out that mortars have not underwent great variations in their external aspect.

In table II, the values of the compressive strength of samples submitted to cycles and those of the initial mortars with no treatment are shown. These values are 
tratamiento. Los valores se obtienen como media de cuatro probetas. Siendo $\mathrm{M} 0$ el mortero con $0 \%$ de sepiolita; M1 el mortero con 1\% de sepiolita; M5 el mortero con $5 \%$ de sepiolita y M5* el mortero con $5 \%$ de sepiolita con el biocida retenido.

Se observa que para los morteros M0, M1 y M5, la resistencia a compresión prácticamente no se modifica y tiene un valor próximo a $4 \mathrm{MPa}$. Además, este valor es similar al que presentaban los morteros iniciales. Con respecto al mortero $\mathrm{M}^{*}$ ( $5 \%$ de sepiolita con biocida retenido), aparentemente tiene un valor superior de resistencia, pero el error de la medida es también superior, por lo que podemos considerar que el valor es similar al del resto de los morteros, y al del mortero sin someter a los ciclos.

En la Tabla III se presentan los valores de la porosidad accesible al agua y densidad aparente, para cada uno de los morteros, comparados con los valores correspondientes al mortero inicial. Cada valor se obtiene como media de tres determinaciones.

Las probetas sometidas a ciclos, presentan valores de porosidad accesible al agua, algo superiores a los del mortero inicial. Únicamente el mortero que tiene un $5 \%$ de sepiolita en su composición, presenta un valor de porosidad algo mas elevado.

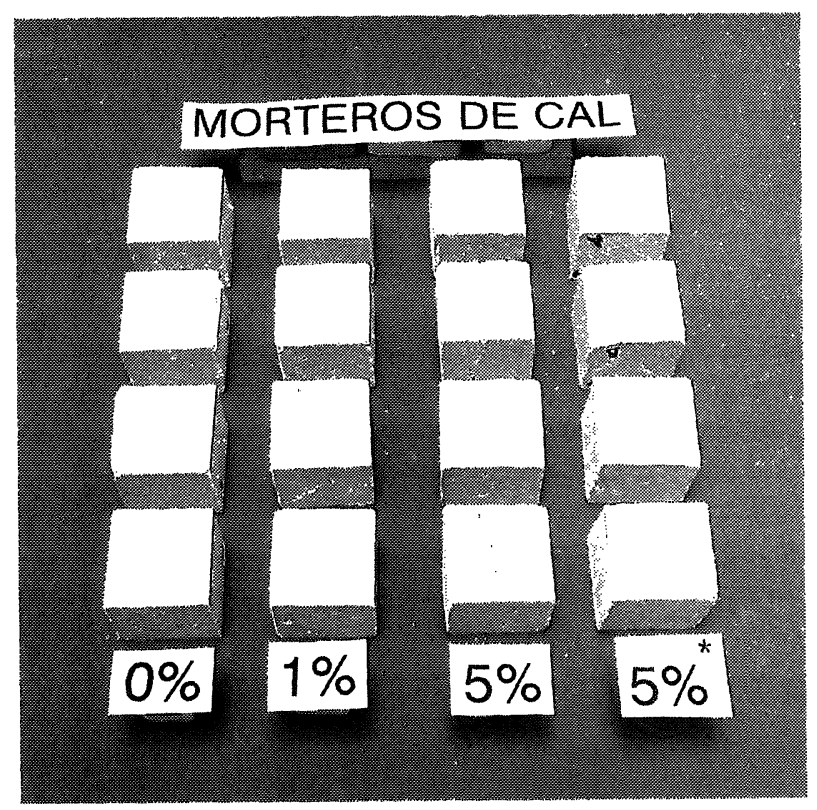

Foto 1.- Morteros de cal con $0 \%, 1 \%, 5 \%$ de sepiolita y $5 \% \%$ (sepiolita $+\mathrm{Cl}_{5} \mathrm{C}_{6} \mathrm{OH}$ ) antes de someterlos a los ensayos de envejecimiento.

Photo 1.- Lime mortars with $0 \%, 1 \%, 5 \%$ of sepiolite and 5\%* (sepiolite $+\mathrm{Cl}_{5} \mathrm{C}_{6} \mathrm{OH}$ ) before ageing tests. obtained as a mean of four specimens strength. Being M0 the mortar with $0 \%$ of sepiolite; M1 the mortar with $1 \%$ of sepiolite; M5 the mortar with $5 \%$ of sepiolite and $M 5^{*}$ the mortar with $5 \%$ of sepiolite and the retained biocide.

For M0, M1 and M5 mortars it is observed that compressive strength does not vary practically and has a value close to $4 \mathrm{MPa}$. Besides, this value is similar to the one that initial mortars have. With respect to $M 5^{*}$ mortar (5\% of sepiolite with biocide retained), apparently, it has a higher strength, but the measurement error is also higher, so this value can be considered similar to the rest of mortars and to the mortar not submitted to the cycles.

In Table III the porosity accesible to water and apparent density values are presented for every mortar, comparing to the corresponding values for the initial mortar. Each value is obtained as a mean of three determinations.

The specimens submitted to cycles, have porosity values, higher than the initial mortar. Only the mortar with 5\% of sepiolite in its composition has a higher porosity value.

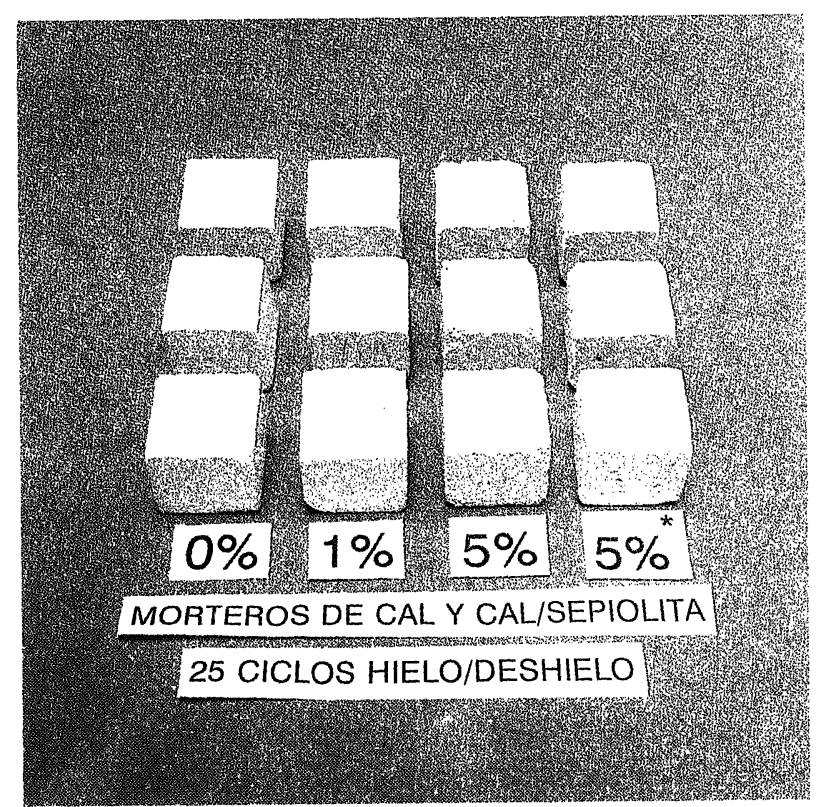

Foto 2.- Morteros de cal, con $0 \%, 1 \%, 5 \%$ de sepiolita y $5 * \%$ (sepiolita $+\mathrm{Cl}_{5} \mathrm{C}_{6} \mathrm{OH}$ ) sometidos a 25 ciclos de hielo/deshiclo.

Photo 2.- Lime mortars with $0 \%, 1 \%, 5 \%$ of sepiolite and 5\%* (sepiolite $+\mathrm{Cl}_{5} \mathrm{C}_{6} \mathrm{OH}$ ) after 25 freeze/thaw cycles. 
TABLA II (TABLE II)

Resistencia a compresión de los morteros sometidos a ciclos (Compressive strength of mortars submitted to cycles)

\begin{tabular}{|c|c|c|}
\hline $\begin{array}{c}\text { MUESTRA } \\
\text { (SAMPLE) }\end{array}$ & $\begin{array}{c}\text { Resist. compr. (MPa) (ciclos) } \\
\text { (Compressive strength (MPa) } \\
\text { (cycles) }\end{array}$ & $\begin{array}{c}\text { Resist. compr. (MPa) (inicial) } \\
\text { Compressive strength (MPa) } \\
\text { (initial) }\end{array}$ \\
\hline M0 & $4,3 \pm 1,5$ & $5,4 \pm 1,0$ \\
M1 & $4,3 \pm 1,3$ & $4,8 \pm 1,5$ \\
M5 & $4,4 \pm 0,9$ & $5,2 \pm 0,5$ \\
M5 & $7,4 \pm 3,4$ & $4,1 \pm 0,5$ \\
\hline
\end{tabular}

TABLA III (TABLE III)

Densidad y porosidad accesible al agua en los morteros sometidos a 25 ciclos hielo/deshielo (Density and porosity accesible to water in mortars submitted to 25 freeze/thaw cycles)

\begin{tabular}{|c|c|c|c|c|}
\hline \multirow[t]{2}{*}{$\begin{array}{l}\text { MUESTRA } \\
\text { (SAMPLE) }\end{array}$} & \multicolumn{2}{|c|}{$\begin{array}{l}\text { MORTERO INICIAL } \\
\text { (INITIAL MORTAR) }\end{array}$} & \multicolumn{2}{|c|}{$\begin{array}{l}\text { MORTERO SOMETIDO CICLOS } \\
\text { (MORTAR SUBMITTED TO CYCLES) }\end{array}$} \\
\hline & $\begin{array}{c}\text { Densidad }\left(\mathrm{g} / \mathrm{cm}^{3}\right) \\
\text { Density }\left(\mathrm{g} / \mathrm{cm}^{3}\right)\end{array}$ & $\begin{array}{c}\text { Porosidad ( } \% \text { volumen) } \\
\text { Porosity (\% volume) }\end{array}$ & $\begin{array}{c}\text { Densidad }\left(\mathrm{g} / \mathrm{cm}^{3}\right) \\
\text { Density }\left(\mathrm{g} / \mathrm{cm}^{3}\right)\end{array}$ & $\begin{array}{l}\text { Porosidad ( } \% \text { volumen) } \\
\text { Porosity (\% volume) }\end{array}$ \\
\hline $\begin{array}{l}\text { M0 } \\
\text { M1 } \\
\text { M5 } \\
\text { M5 }\end{array}$ & $\begin{array}{l}1,81 \pm 0,01 \\
1,80 \pm 0,01 \\
1,73 \pm 0,01 \\
1,75 \pm 0,01\end{array}$ & $\begin{array}{l}30,62 \pm 0,01 \\
30,83 \pm 0,01 \\
30,53 \pm 0,01 \\
30,09 \pm 0,01\end{array}$ & $\begin{array}{l}1,83 \pm 0,1 \\
1,80 \pm 0,01 \\
1,73 \pm 0,01 \\
1,77 \pm 0,01\end{array}$ & $\begin{array}{l}31,53 \pm 0,01 \\
32,46 \pm 0,01 \\
35,17 \pm 0,01 \\
33,90 \pm 0,01\end{array}$ \\
\hline
\end{tabular}

En lo que respecta a la densidad, los morteros con $5 \%$ de sepiolita y $5 \%$ (sepiolita $+\mathrm{Cl}_{5} \mathrm{C}_{6} \mathrm{OH}$ ), presentan un valor algo inferior $\left(1,7 \mathrm{~g} / \mathrm{cm}^{3}\right)$ al de los morteros sin sepiolita y con $1 \%$. Esto se produce tanto antes como después de someterlos a los ciclos hielo/deshielo.

Podemos afirmar que las propiedades físicas y mecánicas de estos morteros sometidos a los ciclos de hielo/deshielo, prácticamente no se ven modificadas por la presencia de sepiolita o sepiolita con biocida (Tabla II y Tabla III).

Los morteros sometidos a los 25 ciclos hielo/deshielo fueron inoculados con dos tipos de microorganismos, Gloeothece sup. y Aspergillus niger, no observándose en ninguno de los casos el crecimiento de los mismos. Por lo que podemos afirmar que las propiedades biocidas se siguen manteniendo en el mortero, aún después de someterlo a los ciclos de hielo/deshielo.
With respect to density, the mortars with $5 \%$ of sepiolite and $5^{*} \%$ (sepiolite $\left.+\mathrm{Cl}_{5} \mathrm{C}_{6} \mathrm{OH}\right)$, have a lower value $\left(1.7 \mathrm{~g} / \mathrm{cm}^{3}\right)$ than mortars without sepiolite and with 1\% of sepiolite. This is produced before and after submitted them to freeze/thaw cycles.

It can be affirmed that physical and mechanical properties of these mortars submitted to freeze/thaw cycles, practically can not be modified by sepiolite or sepiolite with biocide (Table II and Table III).

Mortars submitted to 25 freeze-thaw cycles were inoculated with two kinds of microorganisms, Gloethece sup. and Aspergillus niger, and their growth was not observed. So, it can be affirmed that biocide properties are maintained in the mortar even after submitted it to freeze-thaw cycles. 


\section{2.- Ensayos de cristalización de sales}

\section{1.- Cristalización en medio $\mathrm{NaCl}$}

En la Foto 3 puede verse el aspecto de las probetas después de los 15 ciclos de inmersión/secado y de la eliminación del exceso de $\mathrm{NaCl}$ existente en las muestras. Sobre ellas se determinaron las variaciones de peso; resistencias a compresión; porosidad accesible al agua y densidad aparente, cuyos valores aparecen recogidos en la Tabla IV.

\section{2.- Crystallization tests}

\section{1.- Crystallization in $\mathrm{NaCl}$ medium}

In Photo 3 the aspect of specimens after 15 wet/dry cycles and after removing the $\mathrm{NaCl}$ existent in the samples is shown. The determinations made on them were weight variations; compressive strengths; porosity accesible to water; apparent density, and their values are shown in Table IV.

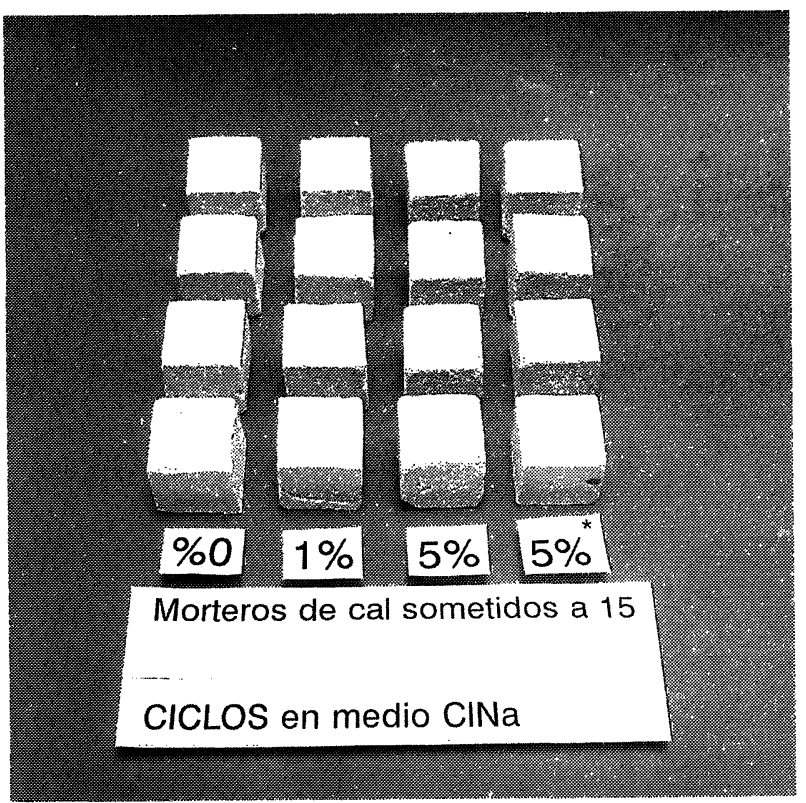

Foto 3.- Morteros de cal con $0 \%, 1 \%, 5 \%$ de sepiolita y $5 * \%$ (sepiolita $+\mathrm{Cl}_{5} \mathrm{C}_{6} \mathrm{OH}$ ) sometidos a 15 ciclos en medio $\mathrm{NaCl}$.

Photo 3.- Lime mortars with $0 \%, 1 \%, 5 \%$ of sepiolite and $5 \% *$ (sepiolite $+\mathrm{Cl}_{5} \mathrm{C}_{6} \mathrm{OH}$ ) after $15 \mathrm{NaCl}$ Crystallization cycles.

TABLA IV (TABLE IV)

Propiedades físico-mecánicas de los morteros sometidos a ciclos de cristalización de $\mathrm{NaCl}$. (Physico-mechanical properties of mortars submitted to $\mathrm{NaCl}$ crystallization cycles)

\begin{tabular}{|c|c|c|c|c|}
\hline $\begin{array}{l}\text { MORTERO } \\
\text { (MORTAR) }\end{array}$ & $\begin{array}{l}\% \text { pérdida } \\
\text { peso } \\
\text { loss of } \\
\text { woigth (\%) }\end{array}$ & $\begin{array}{c}\text { Resistencia } \\
\text { comp. (MPa) } \\
\text { Compressive } \\
\text { strength (MPa) }\end{array}$ & $\begin{array}{c}\text { Porosidad } \\
\text { acc. } \mathrm{H}_{2} \mathrm{O}(\%) \\
\text { Porosity } \\
\text { acc. to water (\%) }\end{array}$ & $\begin{array}{l}\text { Densidad } \\
\left(\mathrm{g} / \mathrm{cm}^{3}\right) \\
\text { Density } \\
\left(\mathrm{g} / \mathrm{cm}^{3}\right)\end{array}$ \\
\hline $\begin{array}{l}\text { M0 } \\
\text { M1 } \\
\text { M5 } \\
\text { M5. }\end{array}$ & $\begin{array}{l}1,5 \pm 0,3 \\
1,2 \pm 0,1 \\
2,2 \pm 0,4 \\
8,4 \pm 1,0\end{array}$ & $\begin{array}{l}8,2 \pm 0,8 \\
6,7 \pm 1,6 \\
5,7 \pm 1,7 \\
8,4 \pm 1,0\end{array}$ & $\begin{array}{l}29,1 \pm 0,01 \\
32,2 \pm 0,01 \\
30,0 \pm 0,01 \\
32,6 \pm 0,01\end{array}$ & $\begin{array}{l}1,8 \pm 0,01 \\
1,8 \pm 0,01 \\
1,7 \pm 0,01 \\
1,7 \pm 0,01\end{array}$ \\
\hline
\end{tabular}


Las variaciones de peso son pequeñas en todos lo casos, próximas al $1 \%$, excepto en el caso del mortero con sepiolita y biocida en el que la pérdida es algo superior al $2 \%$. Estas pérdidas de peso se han podido producir en el proceso de lavado de las probetas para eliminar el exceso de sal existente sobre las mismas.

Los valores de las resistencias a compresión disminuyen ligeramente por la adición de sepiolita al mortero, excepto en el caso de que el mortero presente además biocida, en el que el valor de la resistencia es próximo al de la sepiolita inicial.

Los valores de la porosidad accesible al agua, están cercanos al 30\% del volumen total, siendo ligeramente superiores, para los morteros con $1 \%$ de sepiolita y $5 \%$ (sepiolita $+\mathrm{Cl}_{5} \mathrm{C}_{6} \mathrm{OH}$ ).

Los valores de la densidad aparente no se modifican prácticamente, $\mathrm{y}$ en todos los casos, toman un valor próximo a $1,8 \mathrm{~g} / \mathrm{cm}^{3}$.

Las propiedades físicas estudiadas en los morteros sometidos a los ciclos de cristalización de $\mathrm{NaCl}$, experimentan pequeñas modificaciones cuando se adiciona sepiolita en la composición del mortero. Dichas modificaciones son menores en el caso del mortero con biocida soportado sobre la sepiolita.

Sobre los morteros M5* sometidos a los 15 ciclos se realizó un ensayo de crecimiento de dos tipos de microorganismos:

\section{* Cianobacteria: Gloeothece sup \\ * Hongo: Aspergillus niger}

En los ensayos de crecimiento de microorganismos se observa que las probetas inoculadas con hongos, son rápidamente colonizadas y cubiertas por los micelios de los mismos. En lo que respecta a las cianobacterias, no se observa su crecimiento. Cabe indicar que uno de los ensayos que se realizan para estudiar el crecimiento de microorganismos (9), es la inoculación en medios con elevadas concentraciones de sales tales como sulfatos 0 cloruros. En este caso se trabajó con una disolución saturada de $\mathrm{NaCl}$, cuyo exceso no se eliminó totalmente de las probetas en el proceso de lavado, lo que provocó un medio de cultivo adecuado para el crecimiento de los microorganismos.

El comportamiento de los morteros sometidos a la cristalización de $\mathrm{NaCl}$, es similar al que presentan los morteros iniciales, no modificando su comportamiento por la presencia en el mismo ni de sepiolita, ni de sepiolita con pentaclorofenol. Únicamente destacar el hecho de que en los morteros M5*, se produce el crecimiento de los hongos inoculados, aunque no se produce el crecimiento de las cianobacterias.
Weight variations are small in every case, close to $1 \%$, except in the case of (sepiolite +biocide) mortar in which the weight loss is superior to $2 \%$. These weight losses can be produced in the specimens run-off done to eliminate the salt existing on them.

The compressive strength values decrease slightly by sepiolite addition to the mortar, except in the case in which mortar has biocide, in which the strenght value is close to that of the initial sepiolite.

The values of porosity accesible to water are close to the $30 \%$ of total volume, being slightly superior for mortars with $1 \%$ of sepiolite and $5 \%$ of (sepiolite $+\mathrm{Cl}_{5} \mathrm{C}_{6} \mathrm{OH}$ ).

Apparent density values are not modified practically and in all cases are close to $1.8 \mathrm{~g} / \mathrm{cm}^{3}$.

Physical properties studied in the mortars submitted to $\mathrm{NaCl}$ crystallization cycles, experiment small variations when sepiolite is added to mortar composition. Such modifications are less in the case of the mortar with the biocide supported on the sepiolite.

An experiment testing the growth of two types of microorganisms was done in the M5* mortars submitted to the 15 cycles:

\section{* Cianobacterium: Gloeothece sup. \\ * Fungus: Aspergillus niger}

In the microorganisms growing tests it is observed that specimens inoculated with fungus are quickly colonized and covered with their micellious. With respect to cianobacterium, their growth is not observed. It is worth to point out that one of the tests done to study the microorganisms growth (9), is the inoculation in high salt concentration media such as sulphates or chlorides. In this case the solution was an $\mathrm{NaCl}$ saturated one, which excess was not totally removed in the run-off, and was a suitable culture medium for microorganisms growth.

\section{The behaviour of mortars submitted to $\mathrm{NaCl}$} crystallization is similar to that presented by initial mortars, this is, they don't modify their behaviour by sepiolite or sepiolite and pentaclorophenol presence. Only pointing out that in $M 5^{*}$ mortars, the growth of inoculated fungus is produced, although cianobacteria growth is not. 


\section{2.- Cristalización en medio $\mathrm{Na}_{2} \mathrm{SO}_{4}$}

Este ensayo se basa en el aumento de volumen producido por la recristalización del sulfato sódico en la forma decahidratada a una temperatura de $32.7^{\circ} \mathrm{C}$.

En este medio, las probetas se introdujeron en una disolución al $7 \%$ de $\mathrm{Na}_{2} \mathrm{SO}_{4} \cdot 10 \mathrm{H}_{2} \mathrm{O}$ y se sometieron a ciclos de humedad/secado de manera que en la fase de secado, se producía la cristalización de la fase pentahidratada, cuyo volumen es 10 veces superior al de la fase anhidra. Esta cristalización en el interior de los morteros, produce la rotura de los mismos a los 10 ciclos. En la Foto 4 se muestra el estado en el que quedaron las probetas tras los 10 ciclos.

\subsection{Crystallization in $\mathrm{Na}_{2} \mathrm{SO}_{4}$ medium.}

This test is based in the volume increased produced when sodium sulphate recrystallizes in decahydrate form at $32.7^{\circ} \mathrm{C}$.

In this medium, specimens were immersed in a $7 \%$ $\mathrm{Na}_{2} \mathrm{SO}_{4} \cdot 10 \mathrm{H}_{2} \mathrm{O}$ solution and were submitted to wet/dry cycles, in a way that in the dry phase the crystallization of pentahydrate phase, which volume is 10 times higher than the anhydrous phase, is produced. This crystallization inside mortars, leads to their breakage at 10 cycles, as it can be seen in Photo 4.

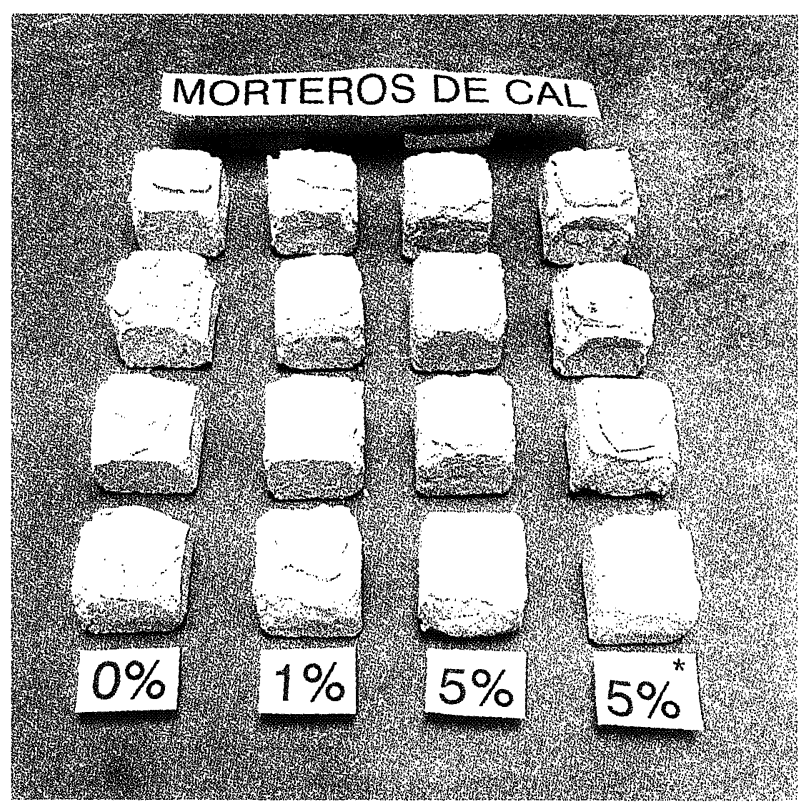

Foto 4.- Morteros de cal con $0 \%, 1 \%, 5 \%$ de sepiolita y $5 * \%$ (sepiolita $+\mathrm{Cl}_{5} \mathrm{C}_{6} \mathrm{OH}$ ) sometidos a 10 ciclos en medio $\mathrm{Na}_{2} \mathrm{SO}_{4}$

Photo 4.- Lime mortars with $0 \%, 1 \%, 5 \%$ of sepiolite and $5 \% *$ (sepiolite $+\mathrm{Cl}_{5} \mathrm{C}_{6} \mathrm{OH}$ ) after $10 \mathrm{Na}_{2} \mathrm{SO}_{4}$ crystallization cycles.

Según Doehne (10), los cristales de $\mathrm{Na}_{2} \mathrm{SO}_{4} \cdot 10 \mathrm{H}_{2} \mathrm{O}$ formados en los ciclos de humedad/secado, tienen un tamaño final que oscila entre 10 y $100 \mu \mathrm{m}$. El mortero de cal presenta un tamaño medio de mesoporo $10^{3} \AA$, que equivale a $0.1 \mu \mathrm{m}$. El tamaño del precipitado final del sulfato decahidratado, según el autor al que antes nos referíamos (10), oscila entre 10 y $100 \mu \mathrm{m}$, tamaño superior al de los poros del mortero. Ello justifica las roturas producidas en los morteros.

Sobre estas probetas también se realizó el ensayo de inoculación y crecimiento de los siguientes microorganismos:
According to Doehne (10), $\mathrm{Na}_{2} \mathrm{SO}_{4} \cdot 1 \mathrm{HH}_{2} \mathrm{O}$ crystals formed during wet/dry cycles, have a final size between $10 \mu \mathrm{m}$ and $100 \mu \mathrm{m}$. Lime mortar has a mean mesopore size of $10^{3} A$, what is equivalent to $0.1 \mu \mathrm{m}$ and a higher size than mortar pores. This explains mortars breakage.

This specimens were also submitted to inoculation and growing tests of the following microorganisms: 
* Cianobacteria: Gloeothece sup.

* Hongo: Aspergillus niger

En este caso no se observó el crecimiento de ninguno de ellos, por lo que estos morteros siguen manteniendo las propiedades biocidas, incluso después de haber perdido gran parte de su cohesión, como puede apreciarse en la Foto 4.

\section{CONCLUSIONES}

El comportamiento frente a los ensayos de envejecimiento acelerado que se han presentado aquí para los morteros de cal con diferentes composiciones de sepiolita, es similar al de los morteros tomados como referencia, y que no presentan dicha arcilla en su composición.

La propiedad biocida de los morteros con sepiolita y biocida retenido se mantiene en los morteros sometidos a los ciclos de hielo/deshielo, en el que no se modifican sustancialmente el resto de las propiedades del mortero. Es por ello por lo que podemos afirmar que ni la presencia de sepiolita ni la de sepiolita con el biocida retenido, modifican el comportamiento de este tipo de morteros frente a ciclos de hielo/deshielo.

Resultados similares se presentan para los morteros de cal sometidos a ciclos de cristalización de $\mathrm{NaCl}$, donde el comportamiento de dichos morteros es similar en presencia y ausencia de sepiolita.

En lo que respecta a los ensayos de cristalización de $\mathrm{Na}_{2} \mathrm{SO}_{4}$ al que se sometieron los morteros, todos ellos pierden la cohesión, no existiendo diferencia de comportamiento por la presencia de sepiolita o de sepiolita con biocida. Además estos morteros mantienen las propiedades biocidas.

\section{AGRADECIMIENTOS}

Los autores desean agradecer a la C.E.E. y a la C.I.C.Y.T. por la financiación a través de los proyectos STEP-CT90-0107 y PAT91-1056, respectivamente.

Las gracias se hacen extensibles también al M.E.C. por la beca de F.P.I. concedida a uno de los autores.

Finalmente queremos mostrar nuestro agradecimiento al Profesor de Investigación Cesareo Sainz Jimenez y al biólogo Javier Ariños, por los ensayos de inoculación y crecimiento de microorganismos realizados sobre las probetas.
* Cianobacteria: Gloethece sup.

* Fungus: Aspergillus niger

In this case, the growth of microorganisms was not observed, so these mortars continue maintaining their biocide properties even after losing a big part of their cohesion, as it is observed in Photo 4.

\section{CONCLUSIONS}

The behaviour of lime mortars with different sepiolite compositions under accelerated aging tests showed here, is similar to the behaviour of reference mortars with no clay in their composition.

The biocide property that sepiolite plus retained biocide mortars have, is maintained when they are submitted to freeze/thaw cycles without variation of the other mortar properties. It can be affirmed that neither sepiolite presence nor sepiolite plus retained biocide modify the behaviour of this kind of mortars under freeze/thaw cycles.

Similar results are showed for lime mortars submitted to $\mathrm{NaCl}$ crystallization tests, where their behaviour is similar with sepiolite and without it.

With respect to $\mathrm{Na}_{2} \mathrm{SO}_{4}$ crystallization tests, all mortars lost cohesion, and there is no difference in the behaviour with the presence of sepiolite or sepiolite plus biocide. Besides, these mortars maintain their biocide properties.

\section{ACKNOWLEDGMENTS}

The authors wish to thank the E.C.C. and C.I.C.Y.T. for financial support through STEP-CT90-0107 and PAT91-1056 projects, respectively.

The authors are also grateful to M.E.C. for the fellowship given to one of the authors.

Finally, thanks to Professor Cesáreo Sáinz Jiménez and the biologist Javier Ariños for the inoculation and growing tests done on samples. 


\section{BIBLIOGRAFÍA}

(1) Conclusiones del Symposium "Mortars, Cements and Grouts used in the Conservation of Historic Buildings", celebrado en Roma del 3 al 6 de Noviembre de 1981.

(2) V. FURLAN. "Causes, mechanisms and measurement of damage to mortars, bricks and renderings". Advanced Workshop Analytical Methodologies for the Investigation of Damaged Stones. Pavia (1990), pp.148-159.

(3) S. MARTÍNEZ-RAMÍREZ; F. PUERTAS AND M.T. BLANCO VARELA “Carbonation process and properties of a new lime mortar with added sepiolite". Cement and Concrete Research, (1995) Vol. 25 No 1, pp 39-50.

(4) Tesis Doctoral de Sagrario Martínez Ramírez presentada en la Universidad Complutense de Madrid (1995).

(5) Norma UNE 67-034-86. Tejas de arcilla cocida. Ensayo de heladicidad.

(6) Norma UNE 80-101. Métodos de ensayo de cementos. Determinación de resistencias mecánicas.

(7) Tentative Recommendations (RILEM). Recommended test to measure the deterioration of stone and to asses the effectiveness of treatment methods. Materiaux et Constructions, (1980), Vol.13, $\mathrm{n}^{\circ 75}$.

(8) Norma ASTM C88-83. Standard test method for soundness of aggregates by use of sodium sulphate or magnesium sulfate.

(9) V. SCHOSTAK; W.E. KRUMBEIN. "Ocurrence of extremely halotolerant and moderate halophilic bacteria on salt impaired wallpaintings". VII ${ }^{\text {th }}$ International Congress on Deterioration and Conservation of Stone, 1992, Lisboa, pp.551-560.

(10) E. DOHENE. "In situ dynamics of sodium sulfate hydration and dehydration in stone pores: observations at high magnification using the environmental scanning electron microscope". III International Symposium of the Conservation of Monuments in the Mediterranean Basin. Venice (1994).

\section{publicación del IETCC/CSIC}

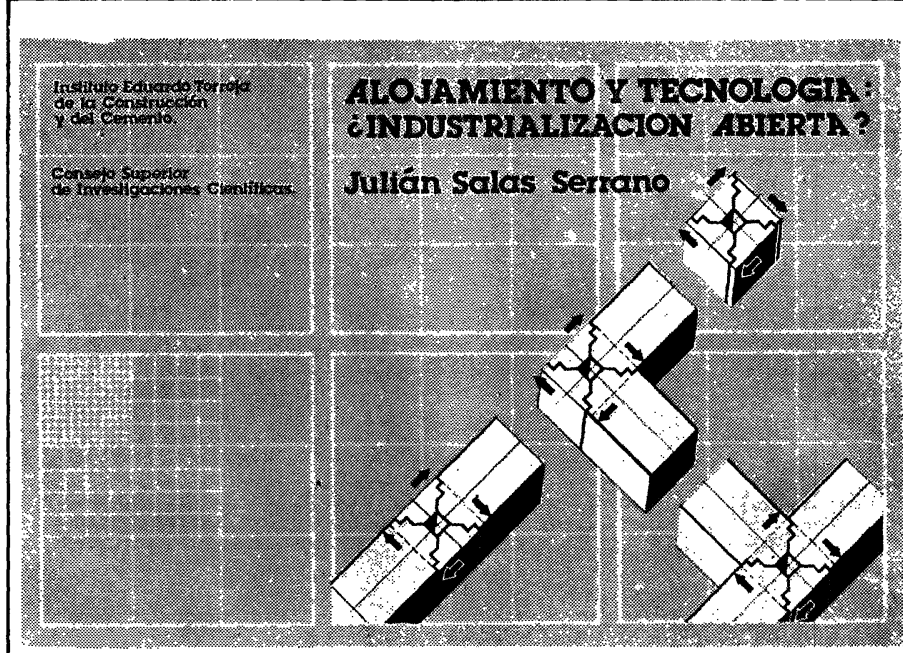

\section{ALOJAMIENTO Y TECNOLOGIA:} ¿INDUSTRIALIZACION ABIERTA?

JULIAN SALAS, ING. IND. (I.E.T.C.c.)

Un volumen de 160 páginas, 109 figuras y 16 tablas. Tamaño $240 \times 168 \mathrm{~mm}$. Encuadernado en rústica. Precios: España, 1.200 ptas; extranjero, 17 \$ USA.

\section{SUMARIO:}

Prólogo Prof. G. Ciribini.

\section{Introducción}

Capitulo 1. - La industrialización en las proclamas y manifiestos de arquitectura.

Capitulo 2. ¿Réquiem por la construcción industrializada?

Capitulo 3. - Algunos conceptos básicos.

Capitulo 4. ¿ ¿Proyecto tradicional, construcción industrializada?

Capitulo 5.-Componentes.

Capitulo 6. - La coordinación dimensional hoy.

Capitulo 7.-Flexibilidad, intercambiabilidad y catálogos.

Capítulo 8. - Industrialización, normativa y calidad.

Capitulo 9.-Reflexiones finales.

publicación del

INSTITUTO EDUARDO TORROJA 